\title{
An Analysis of Production Cost Effect With Order Price Method on Sales Pricing of Products at PT. Aneka Printing Indonesia in Sukoharjo
}

\author{
Maya Widyana Dewi ${ }^{1)}$, Muryati ${ }^{2)}$ \\ Islamic Economic Program \\ Email: Widyamine77@gmail.com
}

\begin{abstract}
This study aims to determine and analyze the calculation of the cost of production of screen printing based on the cost of order method whether it has been in accordance with the theory of cost accounting by comparing the calculation of cost of goods manufactured by the company with the calculation of cost of production based on the cost accounting theory that is using full costing method, As well as to know how much influence the cost of production to the determination of product selling price.

This study uses primary data in the form of information obtained from the owner of the company or parties concerned and secondary data with population and sample data of cost of production and selling price of screen printing orders during January 2017. Data collection methods used are literature research methods, interviews and Method of documentation. While the method of data analysis used is by using simple regression analysis, coefficient of determination and hypothesis test using $t$ test by using the tool program SPSS 16.0 for windows.

From the results of research indicate that the calculation of cost of production based on the results of analysis using full costing method is greater than the calculation of cost of production method company. This difference occurs because the loading of factory overhead cost calculated using full costing method more thorough and detailed. Based on the tests conducted known that the cost of production has a very strong influence on the sale price. The influence of the cost of production to the selling price in this study is $91 \%$, and the remaining $9 \%$ is influenced by other factors (variables) such as demand, supply, and other unreported variables.
\end{abstract}

Keywords: Cost of Production, Selling Price

\section{Introduction}

The developments in the industrial sector have an important role in the economic sector. The progress of the business world is growing rapidly both on a large and small scale. The growing number of industries, creating a competition among similar industries. These companies must have the same goal of gaining profit or profits as much as possible. The component of profit formation is income derived from the sale of production and services produced by the company, while cost is a sacrifice that must be spent by the company to produce or produce something goods or services. The determination of the cost should be appropriateand accurate, so the

cost of goods will also show the real value.Selling price is too high will make the product less competitive in the market, while the selling price is too low will not provide benefits for the company.

The production cost is very influential in the calculation of corporate income, if the 
company is less precise or wrong in determining the cost of production, it will result in an error in the determination of profit and loss obtained by the company. PT. Aneka Printing Indonesiaas one of the companies engaged in the production of screen printing services are also berorentasi on profit,also not apart from the problem of achievement of profit,and payback,in the calculation of cost of goods manufactured.The costs incurred should be used as a benchmark for calculating the establishment of the cost of productsor the selling price of the product itself.

In determining the selling price companies do not use certain methods. However, companies still use traditional counting methods. Selling price is closely related to product quality, if the selling price set by the company is high, then the resulting product quality should be better,because with a good quality will result in an increase in sales turnover, so that the company is expected to maintain the viability of the company (going concern).

By determining the cost of production orders then the company can know the cost of production to be issued. In determining the selling price of an order must be in accordance with the production cost that has been issued by the company to produce the order. So the company can get the optimal profit. Based on the description above then taken the title of research on "An Analysis of Production Cost Effect With Order Price Method on Sales Pricing of Productsat Pt. Aneka Printing Indonesia In Sukoharjo ".

\section{Research Methods}

This research is quantitative that is knowing and analyzing the calculation of basic price of screen printing production based on order cost method whether it has been in accordance with the cost accounting theory by comparing the calculation of the cost of production that has been established by the company with the calculation of cost of production based on cost accounting theory that is using full costing method, as well as to know how much influence the cost of production to the determination of product selling price.

This study uses data of cost of production and selling price of screen printing order during January 2017, so that the sample used in research are 10 samples.

The variables used in this study is the cost of production as an independent variable (X) and selling price as the dependent variable (Y). Cost of Production $(\mathrm{X})$ is the costs incurred in processing raw materials into a product (Mulyadi, 2010).

The data collection method used in this research is Library research (library research), field research (field work research).

\section{Results And Discussion \\ 3.1 Simple Regression Test}

This research uses simple linear regression analysis to measure the influence of the cost of Production Cost as independent variable (X) to Selling Price as dependent variable (Y). Calculate this simple linear regression analysis using SPSS 16.0 (for windows) program.

Table 1. Simple Regression Test Result

Source: Data processed, 2017

\begin{tabular}{|c|c|c|c|c|c|}
\hline \multirow[t]{2}{*}{ Model } & \multicolumn{2}{|c|}{ Unstandardized } & $\begin{array}{l}\text { Standardized } \\
\text { Coefficients }\end{array}$ & \multirow[b]{2}{*}{$t$} & \multirow[b]{2}{*}{ Sig. } \\
\hline & & Std. Error & Beta & & \\
\hline \multirow{2}{*}{$\begin{array}{l}\text { (Constant) } \\
\text { Cost of goods } \\
\text { sold } \\
\text { Production }\end{array}$} & 290.997 & 483.016 & & .602 & .564 \\
\hline & 1.451 & .161 & .954 & 9.003 & .000 \\
\hline
\end{tabular}

The result of the calculation shown in the table above can be taken an assessment of the relationship between the variables of the coefficient of constants and the coefficients 
International Journal of Economics, Business and Accounting Research (IJEBAR)

Peer Reviewed - International Journal

Vol-1, Issue-2, 2017 (IJEBAR)

ISSN: 2614-1280, http://www.jurnal.stie-aas/ijebar

of variables that exist in the Unstandard Coefficients column. Based on this table obtained the equation regression model as follows:

$$
\begin{aligned}
& Y=a+b X \\
& X=\text { Cost of goods sold } \\
& Y=\text { Selling price } \\
& a=\text { Intercept or Constant Value } \\
& b=\text { Figures direction or regression } \\
& \quad \text { coefficient } \\
& Y=290.997+1.451 X
\end{aligned}
$$

\begin{tabular}{|c|c|c|c|c|}
\hline \multicolumn{5}{|c|}{ January, 2017} \\
\hline No & Buyer's Name & $\begin{array}{l}\text { Code } \\
\text { Pants }\end{array}$ & $\begin{array}{l}\text { Print } \\
\text { Type }\end{array}$ & $\begin{array}{l}\text { Order } \\
\text { amount } \\
\text { (Pes) }\end{array}$ \\
\hline 1 & \multirow{4}{*}{$\begin{array}{l}\text { PT. Asrindo Indty } \\
\text { Raya }\end{array}$} & 287 & Rubber & 12.500 \\
\hline 2 & & 321 & Foaming & 5.000 \\
\hline 3 & & 322 & Rubber & 4.142 \\
\hline 4 & & 294 & Joll HD & 8.000 \\
\hline 5 & \multirow{5}{*}{$\begin{array}{l}\text { PT. Semarang } \\
\text { Garment }\end{array}$} & 331 & Foil & 4.000 \\
\hline 6 & & 380 & Joll HD & 2.000 \\
\hline 7 & & 284 & Rubber & 4.000 \\
\hline 8 & & 286 & Rubber & 4.000 \\
\hline 9 & & 283 & Rubber & 4.000 \\
\hline 10 & PT. Sari Warna & Avirex & Rubber & 16.208 \\
\hline mou & & & & 63.850 \\
\hline
\end{tabular}

Table 2.

Sablon Order Data PT. AnekaPrinting

Source: Data processed, 2017

The amount of production cost incurred by Aneka Printing in January 2017 as follows:

\section{a. Paying Raw Materials}

The cost of raw materials is the cost of

\begin{tabular}{|c|c|c|c|c|}
\hline & Cat white rubber ri & 20 & 63.100 & 1.262 .000 \\
\hline & Cat pigmen blue & 7 & 125.000 & 875.000 \\
\hline & Cat pigmen $\mathrm{f} / \mathrm{blue}$ & 5 & 104.000 & 520.000 \\
\hline & Cat pigmen $\mathrm{f} /$ violet & 6 & 155.000 & 930.000 \\
\hline & Total & 88 & & 6.892 .000 \\
\hline \multirow[t]{3}{*}{322} & Cat 1500 white paste & 30 & 58.600 & 1.758 .000 \\
\hline & Cat pigmen black & 7 & 57.000 & 399.000 \\
\hline & Total & 37 & & 2.157 .000 \\
\hline \multirow[t]{6}{*}{294} & Cat black plastisol & 20 & 78.100 & 1.562 .000 \\
\hline & Cat 711 clear 3D & 40 & 92.700 & 3.708 .000 \\
\hline & Cat white plastisol & 25 & 77.550 & 1.938 .750 \\
\hline & Cat red plastisol & 10 & 120.300 & 1.203 .000 \\
\hline & Cat F/blue plastisol & 10 & 131.850 & 1.318 .500 \\
\hline & Total & 105 & & 9.730 .250 \\
\hline \multirow[t]{3}{*}{331} & Foil Black & 8 & 335.100 & 2.680 .800 \\
\hline & Lem Foil 888C & 10 & 113.600 & 1.136 .000 \\
\hline & Total & 18 & & 3.816.800 \\
\hline \multirow[t]{4}{*}{380} & Cat black plastisol & 15 & 78.100 & 1.171 .500 \\
\hline & Cat white plastisol & 20 & 77.550 & 1.551 .000 \\
\hline & Cat 711 clear 3D & 10 & 92.700 & 927.000 \\
\hline & Total & 45 & & 3.649.500 \\
\hline \multirow[t]{7}{*}{284} & Cat 1500 white paste & 43 & 58.600 & 2.519 .800 \\
\hline & Cat 1500 clear paste & 25 & 58.600 & 1.465 .000 \\
\hline & Cat pigmen black & 5 & 57.000 & 285.000 \\
\hline & Cat pigmen f/yellow & 10 & 85.000 & 850.000 \\
\hline & Cat pigmen pink & 3 & 36.000 & 108.000 \\
\hline & Cat pigmen blue & 2 & 125.000 & 250.000 \\
\hline & Total & 88 & & 5.477 .800 \\
\hline \multirow[t]{4}{*}{286} & Cat 1500 white paste & 35 & 58.600 & 2.051 .000 \\
\hline & Cat pigmen red & 10 & 101.000 & 1.010 .000 \\
\hline & Cat pigmen black & 6 & 57.000 & 342.000 \\
\hline & Total & 51 & & 3.403.000 \\
\hline
\end{tabular}
raw materials used in processing the product (Supriyono, 2011).

Table 3.

Raw Material Cost PT. Aneka Printing January, 2017

\begin{tabular}{|l|l|l|l|l|}
\hline Kode & Kind of raw material & $\begin{array}{l}\text { Unit } \\
(\mathbf{K g})\end{array}$ & $\begin{array}{l}\text { Unit } \\
(\mathbf{R p})\end{array}$ & $\begin{array}{l}\text { Total } \\
(\mathbf{R p})\end{array}$ \\
\hline \multirow{3}{*}{287} & Cat 1500 white paste & 40 & 58.600 & 2.344 .000 \\
\cline { 2 - 5 } & Cat pigmen black & 10 & 57.000 & 570.000 \\
\cline { 2 - 5 } & Cat 1500 clear paste & 17 & 58.600 & 996.200 \\
\cline { 2 - 5 } & Total & $\mathbf{6 7}$ & & $\mathbf{3 . 9 1 0 . 2 0 0}$ \\
\hline \multirow{2}{*}{321} & Cat Foaming Binder & 50 & 66.100 & 3.305 .000 \\
\hline
\end{tabular}

\section{b. Direct Labot Cost}

Direct labor costs are labor costs or wages directly related to production, which are employed to process raw materials into finished goods (Mulyadi, 2014).

Table 4.

Direct Labor Cost PT. Aneka Printing Indonesia January, 2017 Source: Data processed, 2017 
International Journal of Economics, Business and Accounting Research (IJEBAR)

Peer Reviewed - International Journal

Vol-1, Issue-2, 2017 (IJEBAR)

ISSN: 2614-1280, http://www.jurnal.stie-aas/ijebar

\begin{tabular}{|c|l|l|}
\hline No & Code Orders & $\begin{array}{l}\text { Total } \\
\text { (Rp) }\end{array}$ \\
\hline 1 & 287 & 2.346 .120 \\
\hline 2 & 321 & 4.135 .200 \\
\hline 3 & 322 & 1.294 .200 \\
\hline 4 & 294 & 5.838 .150 \\
\hline 5 & 331 & 2.290 .080 \\
\hline 6 & 380 & 2.189 .700 \\
\hline 7 & 284 & 3.286 .680 \\
\hline 8 & 286 & 2.041 .800 \\
\hline 9 & 283 & 4.357 .500 \\
\hline 10 & AVIREX & 1.855 .800 \\
\hline \multicolumn{2}{|c|}{ Total Factory Overhead Cost } & $\mathbf{2 9 . 6 3 5 . 2 3 0}$ \\
\hline
\end{tabular}

\section{c. Factory Overhead Costs}

The factory overhead cost is an element of production cost in addition to the cost of raw materials and direct labor costs incurred during the production process (Siregar et al, 2013).

The Company has set the percentage of factory overhead cost of $60 \%$ of raw material cost incurred. The details of factory overhead costs can be seen in the following table:

Table 5.

Factory Overhead Cost PT. Aneka Printing Indonesia January, 2017

\begin{tabular}{|c|c|c|c|c|c|}
\hline $\begin{array}{l}\text { Code } \\
\text { Orders }\end{array}$ & Information & $\begin{array}{l}\text { amount } \\
\text { Worker }\end{array}$ & $\begin{array}{l}\text { Week } \\
\text { day }\end{array}$ & $\begin{array}{l}\text { Wage } \\
\text { /day } \\
\text { (Rp) }\end{array}$ & $\begin{array}{l}\text { Total } \\
\text { (Rp) }\end{array}$ \\
\hline \multirow[t]{4}{*}{287} & Pekerja Sablon II & 3 & 7 & 77.000 & 1.617 .000 \\
\hline & Helper I & 2 & 7 & 65.000 & 910.000 \\
\hline & Helper II & 2 & 7 & 58.600 & 820.400 \\
\hline & \multicolumn{4}{|l|}{ Total } & 3.347 .400 \\
\hline \multirow[t]{4}{*}{321} & Pekerja Sablon I & 2 & 8 & 102.000 & 1.632 .000 \\
\hline & Helper I & 3 & 8 & 65.000 & 1.560 .000 \\
\hline & Helper II & 3 & 8 & 58.600 & 1.406 .400 \\
\hline & \multicolumn{4}{|l|}{ Total } & 4.598 .400 \\
\hline \multirow[t]{3}{*}{322} & Pekerja Sablon II & 2 & 3 & 77.000 & 462.000 \\
\hline & Helper II & 3 & 3 & 58.600 & 527.400 \\
\hline & \multicolumn{4}{|l|}{ Total } & 989.400 \\
\hline
\end{tabular}

Source: Data processed, 2017

\section{d. Cost of Goods Sold}

Manufacturing cost is the costs directly related to the production process of direct material costs, direct labor costs and factory overhead costs (Firdaus Ahmad, 2012). The calculation of the cost of production in January 2017 is as follows:

Table 6.

Calculation of Production Cost of Screen Printing Pt. Aneka Printing Indonesia January, 2017

\begin{tabular}{|l|l|l|l|l|l|l|}
\hline \multirow{2}{*}{ Code } & \multicolumn{3}{|c|}{ Elemen Biaya } & & \\
\cline { 2 - 7 } & $\begin{array}{l}\text { Raw } \\
\text { Material } \\
\text { Rp) }\end{array}$ & $\begin{array}{l}\text { Labor } \\
\text { Rp) }\end{array}$ & $\begin{array}{l}\text { Factory } \\
\text { Overhead } \\
\text { Rp) }\end{array}$ & $\begin{array}{l}\text { Total HPP } \\
\text { Rp) }\end{array}$ & Orders & $\begin{array}{l}\text { HPP Untit } \\
\text { Rp) }\end{array}$ \\
\hline 287 & 3.910 .200 & 3.347 .400 & 2.346 .120 & 9.603 .720 & 12.500 & 768 \\
\hline 321 & 6.892 .000 & 4.598 .400 & 4.135 .200 & 15.625 .600 & 5.000 & 3.125 \\
\hline 322 & 2.157 .000 & 989.400 & 1.294 .200 & 4.440 .600 & 4.142 & 1.072 \\
\hline 294 & 9.730 .250 & 9.078 .000 & 5.838 .150 & 24.646 .400 & 8.000 & 3.081 \\
\hline 331 & 3.816 .800 & 4.044 .800 & 2.290 .080 & 10.151 .680 & 4.000 & 2.538 \\
\hline 380 & 3.649 .500 & 1.806 .000 & 2.189 .700 & 7.645 .200 & 2.000 & 3.823 \\
\hline 284 & 5.477 .800 & 6.196 .800 & 3.286 .680 & 14.961 .280 & 4.000 & 3.740 \\
\hline 286 & 3.403 .000 & 2.684 .000 & 2.041 .800 & 8.128 .800 & 4.000 & 2.032 \\
\hline 283 & 7.262 .500 & 4.647 .600 & 4.357 .500 & 16.267 .600 & 4.000 & 4.067 \\
\hline Avire & 3.093 .000 & 2.589 .000 & 1.855 .800 & 7.537 .800 & 16.208 & 465 \\
\hline Total & 49.392. & 39.981. & 29.635. & 119.008. & 63.850 & \\
\hline & 050 & 400 & 680 & & \\
\hline
\end{tabular}

\subsection{Results of Coefficient of Determination $\left(\mathbf{r}^{2}\right)$}

Table 7.

Coefficient of Determination

\begin{tabular}{|l|l|l|l|l|}
\hline Model & R & R Square & $\begin{array}{l}\text { Adjusted R } \\
\text { Square }\end{array}$ & $\begin{array}{l}\text { Std. Error of the } \\
\text { Estimate }\end{array}$ \\
\hline 1 & $954^{\mathrm{a}}$ & .910 & .899 & 694,268 \\
\hline
\end{tabular}

Source: Data processed, 2017

The coefficient of determination $\left(\mathrm{r}^{2}\right)$ of the simple regression results shows the clarity of the change in the dependent variable. 
Then the value of the coefficient of determination $\left(\mathrm{r}^{2}\right)$ of 0.910 is close to the number one, indicating the cost of production has a very big influence on the selling price. The effect of variable $(\mathrm{X})$ is the cost of production to the variable (Y) selling price is $91 \%$, while the remaining $9 \%$ is influenced by demand and supply and other variables that are not examined. From the regression equation it can be concluded that any increase in the cost of production will be followed by an increase in the selling price of Rp.1.451.00.

\subsection{Hypothesis Testing}

3.3.1 H1: calculation of the cost of production of the company has been in accordance with the cost of order method according to cost accounting theory.

Based on the analysis that has been done shows that the cost of production company is Rp. 119.008.680,00. While the cost of production produced by using the full costing method based on the analysis is $\mathrm{Rp}$. $128.417 .864,00$ so there is a difference of Rp. 9.409.184.00. This difference occurs because the costs that should be taken into account as an element of cost in production are not taken into account. These costs are factory overhead costs including fixed factory overhead costs and variable factory overhead costs. PT. Aneka Printing Indonesia imposes a factory overhead cost of $60 \%$ of raw material usage. So there is no detailed calculation for the actual costs occur either fixed overhead or variable, it can be said that $\mathrm{H}_{1}$ is rejected which means that the calculation of the cost of production company is not in accordance with the cost of order method according to cost accounting theory.

The equation of the result of this research with the result of previous research, Ahmad Nur Al Yudha (2013) is on the problem studied namely about the calculation of cost of production by using the full costing method so that the calculation of cost of production produced higher using the full costing method compared with the company method.

3.3.2 H2: the cost of production affects the determination of the selling price.

From table 4:14 above can be seen the value of sig variable $\mathrm{X}$ (Cost of Production) on the table of $0.000<0.05$, it can be said that $\mathrm{H} 2$ accepted, which means the cost of production affect the selling price. While the value of $t_{\text {count }}$ shows the value of 9.003 is greater than the $t_{\text {table }}$ is $9.003>1.860$.

So it can be concluded there is a significant influence between the variable cost of production to the variable selling price. So, if the cost of production increases, then the selling price will also go up. This is in line with research conducted by Angga Pratama (2012), Novita Serliana and Yani Restiani Widjaja (2012), R. Bambang Dwi Waryanto and Nasrulloh (2014) that the cost of production has a significant effect on the selling price.

\section{Conclusion}

Based on the analysis and discussion in the previous chapter, it can be concluded as follows:

4.1 PT. Aneka Printing Indonesia in the determination of the cost of production has not shown the maximum cost of production so it is not in accordance with the correct accounting method. Based on the analysis that has been done with the accounting method, obtained the value of higher production costs because the cost is in the production process is calculated in detail. The difference in production costs is due to the calculations applied by the company not detailing all the costs incurred during the production process.

4.2 The difference between the calculation of the results of the analysis using full costing method with methods undertaken by PT. Aneka Printing Indonesia lies in the calculation of 
factory overhead cost. PT. Aneka Printing Indonesia imposes a factory overhead cost of $60 \%$ of raw material usage. So there is no detailed calculation for the actual cost of both fixed and variable overheads. So the result was less precise and accurate. Errors in the calculation of cost of goods sold can affect the determination of the selling price and profit desired by a company.

4.3 Based on hail testing that has been done, it can be concluded that the cost of production has a very strong and large influence on the selling price of $91 \%$ and the remaining 9\% influenced by other variables, such as demand, supply and other variables that are not examined .

\section{Suggestion}

Suggestions that can be given in this research include:

5.1 Should PT. Aneka Printing Indonesia uses the calculation with full costing method in calculating the cost of production. Because this method details all the costs incurred during the production process in detail the costs incurred as well as the cost is also very big effect on the sale price determination. With the correct cost of goods production information, it can be used as a reference base for decision making in determining the selling price. So that decisions can be taken correctly and can support the success of the company in the future..

5.2 For the next researcher, who is interested to study similar aspect is expected to research with longer period, add another variable in research that can influence the selling price of a product, and expected to add other method in calculation of product cost so that more an alternative to obtaining an accurate and efficient product cost point.

\section{Bibliography}

Andayani, W. 2014. Determination of the Cost of Production of Catfish On Farmers Catfish In District Sukowono Jember. Skripsi. Jember State University.

Basu Swastha Dharmmesta. Module

7 Pricing Strategy, page. 1

Daljono. 2011. Cost Accounting, Costing Determination and Control. Third Edition. Second printing. BP Undip. Semarang.

Dunia, Firdaus A. dan Wasilah Abdullah. 2012. Cost accounting. Jakarta: Salemba Empat.

Kusuma, Indra Lila. Dan Maya Widyana Dewi. 2017.

Guidelines for Thesis Writing S1 Accounting Study Program.AAS: Surakarta

Maftukhah, Raras. 2016. The Influence of Production Costs in Determining the Selling Price of Pillow and Sapanyana Flooring Factory of Dawuhan Wetan Village, Kedung Banteng, Banyumas, Jawa Tengah. Skripsi. Purwokerto: Bachelor Program of Islamic State Institute Purwokerto

Mulyadi. 2010. Cost accounting. Fifth Edition, Seventh Print. Publishing and Printing Unit (UPP) STIM YKPN. Yogyakarta.

2012. Akuntansi Biaya. Edisi

Kelima, Cetakan Kesebelas. Unit Penerbit dan Percetakan (UPP) STIM YKPN. Yogyakarta.

. 2014. Cost accounting. Fifth

Edition, Twelve Print. Publishing and Printing Unit (UPP) STIM YKPN. Yogyakarta.

Noordina Fourqoni. 2014. Production Costing Analysis Based on Full Costing Method In Making Cupboard Ornamental And Sofa At Ainun Jati Meubel.Skripsi..Jember State University.

Nur, Al Yudha, Ahmad. 2013. Analysis of 
ISSN: 2614-1280, http://www.jurnal.stie-aas/ijebar

Costing Principles of Print

Production by Using Full Costing

Method on CV. Global

Sejahtera.Skripsi. Semarang: Dian

Nuswantoro University.

Pratama, Angga. 2012. Effect of Production Cost on Sales Price (Case Study at Tasikmalaya Latitude Company). Skripsi. Economics Faculty. Siliwangi University.

Serliana, Novita dan Yani Restiani Widjaja. 2012. The Influence of Cost of Production on Selling Price of T-Shirt Products at CV. Tridharma Persada Bandung. Skripsi. Bandung: Bachelor Program BSI University.

Simamora. 2012. Manajemen Accounting. Third edition, First Printing. Yogyakarta: Star Gate Publisher.

Siregar et al. 2013. Cost accounting. Jakarta:Erlangga.

Sugiyono. 2010. Statistics for research. Alfabeta Publisher. Bandung. 2013. Qualitative Research Methods and Quantitative And $R \&$ $D$. Bandung: Alfabeta.

Supriyono. RA. 2011 Cost Accounting for Cost Collection and Costing. Fifteenth Print.. BPFE. Yogyakarta. . 2013. Cost Accounting, and Costing Pricing. Book One. Second Edition. Eighteen Prints. BPFE. Yogyakarta.

Waryanto, R. Bambang Dwi and Nasrullah. 2014. The Influence of Determination of Cost of Production on Sale Price at Krupuk Industry: Case Study at UD. Inun Jaya Sampang. Economy Magazine. Volume XVIII: 208-218. 